\title{
DYNAMISM VS. STABILITY IN UKRAINIAN TAXATION
}

\section{Kravchuk O. 0.}

\section{INTRODUCTION}

Tax legislation of Ukraine is constantly changing. New taxes are being introduced; the old ones are being abolished. The existing taxes are being renamed. New mechanisms of tax administration are being introduced and existing mechanisms are constantly changing. All this is accompanied by organizational reform. The state tax bodies are being established, restructured, winded up or renamed. In 2019 the State Fiscal Service was divided into the State Tax Service and State Customs Service. Previously they were united in 2012 and named Ministry of Revenue and Duties ${ }^{1}$.

Among the most important functions of taxation are promoting and regulating functions, due to which the state regulates (or should regulate) economic processes and ensures an economic growth. That is why the Ukrainian government has been looking for the best set of taxes since the independence and until today (including tax rates and taxable items), which will give a possibility to meet political, economic and other demands in the nearest years and ensure economic growth in the future.

Unfortunately, each year the taxation reforms are carried out in violation of the stability principle established by the law, without proper transition period, which in many cases allows business to adapt its activity to new terms resulting in negative impact on relations between the government and business, as it reduces essentially trust of business with regard the government.

Our purpose in this work is to consider system disadvantages hindering compliance with the taxation stability principle, to develop the approaches in tax and legal regulation, which should ensure prevention from its violation.

1 Про Міністерство доходів і зборів України. Указ Президента України від 18 березня 2013 р. № 141/2013. URL: https://zakon.rada.gov.ua/laws/show/141/2013 (дата звернення: 02.09.2019); Про утворення Державної фіскальної служби. Постанова Кабінету Міністрів України від 21 травня 2014 р. № 160. URL: https://zakon.rada.gov.ua/ laws/show/160-2014-п (дата звернення: 02.09.2019). 
Necessity to achieve this goal promotes a solution of this general economic and legal issue of legal coverage of developing businessfriendly governance and investment attractive economy in Ukraine.

Ukrainian scientists I.S. Volokhova, D.O. Hetmantsev, O.R. Zeldina, Yu.A. Koval, M.P. Kucheriavynko, H.N. Meskhiia, O.A. MusykaStefenchuck, M.V. Nechai, L.V. Tovkun, I.V. Yasko and others have considered the taxation principles, in particular, stability principle, in their works. We will consider the system trends with regard to non-compliance with the stability principle, typical for domestic tax policy, and we will define the direction of its improvement. Opinions, propositions and approaches with regard to operation of law in time (timely publishing, establishment of transition period, procedure for entering into force) and with regard to legal writing have a basic legal bearing.

D.O. Hetmantsev, Yu.A. Koval, M.V. Nechai note that the taxation stability principle is a mechanism of compliance with the taxation certainty, envisaging, on the opinion of Adam Smith, that the taxpayers should be aware in advance of the amount, type, time of payment ${ }^{2}$.

When talking about system violation of the taxation stability principle, we understand, first of all, the next system trends, which will be gradually analysed in our work.

- non-compliance with the rules of law with regard to enforcement of tax and legal regulations with a transition period of not less than 6 months;

- adoption of tax laws in package with the State Budget empathizing absence of taking into account strategic and long-term goals in legal regulation of taxation, and on the contrary its subordination, first of all, to the current governmental purposes and tasks;

- more frequent, in comparison with adoption of other laws, availability of technical errors in the text of the tax laws based on its significant volume, quick passing through the parliament (basically an express consideration, sometimes in a package with the budget);

- sometimes absence even of a minimum transition period;

- quick radical changes without privilege period (with regard to penalties);

- laws publication with delay;

${ }^{2}$ Гетманцев Д.О., Коваль Ю.А., Нечай М.В. Адміністрування податкових платежів: проблеми теорії та практики: наук.-практ.посіб. - К., 2017. - С. 50. 
- introduction and abolition of the retail taxes (affecting a wide segment of people and retailers) upon the date of publication (essentially day-to-day);

- imposition of the new tax without compliance with the stability principle.

In the process of consideration of the issue, we will show the examples of the changes of the tax laws adopted in violation of the taxation stability principle. Having no intention to itemize them, we will show consistency and stability of this issue in order to develop its efficient solution.

\section{Main violations of stability principle}

Non-compliance with the 6-month transition period. The stability principle in the tax law of Ukraine appeared in the Law of Ukraine “On Taxation System”, as amended by Law No. 3904-XII as of February 02, 1994 in accordance with Article 7, envisaging that taxation rate and amounts of other binding payments shall not be changed within the fiscal year, unless otherwise provided for by the legislative instruments of Ukraine ${ }^{3}$.

This amended Law, as it was set forth by Law No. 77/97-BP as of February 18, 1997 that entered into force as of March 20, 1997, contained the rule, pursuant to which the amendments and additions to this Law, to other Laws of Ukraine on Taxation with regard to the benefits, taxation rates and duties (binding payments), the mechanism of payment thereof shall be introduced to this Law, other laws of Ukraine on taxation not later than six months prior to the beginning of a new fiscal year and shall enter into force from the beginning of a new fiscal year. This new version of the Law (in Article 3) contains a legal list of the principles of the taxation system. The stability principle was laid down as follows: "stability means ensuing invariability of taxes and duties (binding payments) and their rates, as well as tax benefits during a fiscal year"4.

${ }^{3}$ Про систему оподаткування. Закон України. В редакції Закону України «Про внесення змін і доповнень до Закону Української РСР «Про систему оподаткування»» від 2 лютого 1994 року № 3904-XII. URL: https://zakon.rada.gov.ua/laws/show/3904-12/ ed19940401 (дата звернення: 02.09.2019).

${ }^{4}$ Про внесення змін до Закону України «Про систему оподаткування». Закон України від 18 лютого 1997 року № 77/97-BP. URL: https://zakon.rada.gov.ua/laws/ show/77/97-вp/ed20000331 (дата звернення: 02.09.2019). 
Approximately in this version (with the regulation with regard to amendments to the tax laws should be available at least 6 months prior to the beginning of the fiscal year), the stability principle was envisaged in all further laws defining the system and principles of taxation, particularly, in the current Tax Code of Ukraine.

In some new versions, the Parliament envisaged the possibility of waiving this rule, however, for the most part the Parliament was not concerned about it and, if necessary, they amended the tax laws and brought them into force immediately or with a much shorter transition period than 6 months.

Thus, part 5 of Article 1 of the Law “On Taxation System”, as amended by Law No. 1523-III as of March 02, 2000, envisaged that amendments to this Law, other laws of Ukraine on taxation in respect of granting privileges, changes in taxes, duties (binding payments), the mechanism of payment thereof shall be introduced to this Law, other laws of Ukraine on taxation not later than six months prior to the beginning of a new fiscal year and shall enter into force from the beginning of a new fiscal year. However, this part established the following conclusion: this rule shall not be applied in cases of reduction of the amount of tax rates, duties (binding payments) or cancellation of the taxation benefits and other rules causing violation of the rules of competition and creation of tax privileges to the certain business entities or individuals ${ }^{5}$.

In general, such conclusion raises a quite important philosophic and legal issue: if the statute is deficient, unlawful or there is another important system problem then why should we wait for full 6 months if we may change or abolish this regulation now?

However, the philosophic and legal answer to this question is obvious: the legislator, showing his own unwillingness to comply with the law, demonstrates absence of the rule of law in Ukraine. After all, one element of the concept of the rule-of-law state is that the state is not above the law, but itself is bound by the rules of law. The legislator (as a public authority) is also bound by the rules of law.

It is considered that the body of legislative power should first and foremost consistently demonstrate adherence to the rule of law in its activities. It is the Parliament that sets the pace for functioning of the

${ }^{5}$ Про внесення змін до деяких законодавчих актів України з питань оподаткування. Закон України від 2 березня 2000 р. № 1523-III. URL: https://zakon.rada.gov.ua/ laws/show/1523-14/ed20040101 (дата звернення: 02.09.2019). 
entire legal system. Of course, both the Government and the President do not have to draft and submit to the Parliament any bills on amendments with regard to the issues of taxation (now - the Tax Code) that do not provide for at least a 6-month transition period. Unfortunately, the Government and the Head of the State today do not follow this approach, showing the intentions to implement radical tax changes without observing the transition period. It is not always possible to make them pass through the Parliament, but use of such approaches by the Government is also not beneficial to development of the rule of law in Ukraine. For example, on October 05, 2017, the government news portal reported that the Government had approved the draft law on Tax on Withdrawn Capital and intended to implement it from $2018^{6}$.

The President of Ukraine submitted to the Parliament the draft law on Amendments to Tax Code of Ukraine on Tax on Withdrawn Capital on July 5, 2018 (draft law No. 8557 as of July 05, 2018); this draft law was marked by the President as urgent ${ }^{7}$. It envisaged that the law would enter into force on January 01, 2019 (i.e. without observing the stability principle). In 2019 after new President and Parliament elections a lot of bills on amendments to the Tax Code were introduced without observing the transition period ${ }^{8}$.

Pursuant to sub-paragraph 4.1.9. of the Tax Code of Ukraine, stability is one of the principles serving the basis for the tax legislation of Ukraine ${ }^{9}$. And according to this principle, changes to any elements of taxes and fees may not be made later than six months before the start of the new budget period in which the new rules and rates will apply; taxes and fees, their rates, and tax relief cannot be changed during the fiscal year. The regulation in this wording has existed since the initial revision of the Code of 2010. However, tax changes are very common, including the radical ones, introduced without observance of the transition period.

${ }^{6}$ Уряд схвалив законопроект щодо запровадження податку на виведений капітал. URL: https://www.kmu.gov.ua/ua/news/250326805 (дата звернення: 02.09.2019).

7 Картка законопроекту. Проект Закону про внесення змін до Податкового кодексу України щодо податку на виведений капітал. Реєстр. №8557 від 05.07.2018. URL: http://w1.c1.rada.gov.ua/pls/zweb2/webproc4_1?pf3511=64356 (дата звернення: 02.09.2019).

${ }^{8}$ Економічні законопроекти від нових депутатів, зареєстровані в ВРУ. ДебетКредит. URL: https://news.dtkt.ua/state/laws-and-regulations/57423 (дата звернення: 02.09.2019).

${ }_{9}^{9}$ Податковий кодекс України від 2 грудня 2010 p. URL: https://zakon.rada.gov.ua/ laws/show/2755-17/ed20190101 (дата звернення: 02.09.2019). 
For example, Law No. 71-VIII "On Amendments to Tax Code of Ukraine and Certain Legislative Instruments of Ukraine on Tax Reform”, known among Ukrainian businesses, was adopted on December 28, 2014. It entered into force on January 01, 2015. This Law radically changed the taxation system, changed the list of taxes; the taxation mechanism in the part of the corporate income tax has been radically changed (essentially a new object of taxation with this tax was introduced accounting income adjusted for the difference stipulated by the law, instead of the financial result calculated according to the rules of tax accounting) - section III of the Code "Corporate Income Tax" was stated completely in a new wording ${ }^{10}$.

If the state has adopted a certain concept - as noted with regard to the stability of tax legislation by D.O. Hetmantsev, Yu.A. Koval, M.V. Nechai, then it acts unlawfully if it deviates from the stated behaviour or policy ${ }^{11}$.

Adoption of changes simultaneously with the State Budget. The taxation stability principle is associated with the principle of early promulgation of laws affecting the revenue or expenditure part of budgets contained in the Budget Code of 2001 (Article 27) ${ }^{12}$ and contained in the current Budget Code 2010 (Article 27). According to the current wording of Part 3 Article 27 of the Budget Code, laws of Ukraine or separate provisions thereof, that affect budget indicators (reduce budget revenues and/or increase budget expenditures) and are adopted: not later than the $15^{\text {th }}$ of July of the year preceding the planning one, and shall be enacted not earlier than the beginning of the planned budget period; after the $15^{\text {th }}$ of July of the year preceding the planning one, and shall be enacted not earlier than the beginning of the budget period following the planning one ${ }^{13}$.

Important, although according to the abovementioned approach, the negative Ukrainian tradition is to adopt amendments to tax laws simultaneously with the State Budget for the relevant year. In due course, the Parliament practiced incorporating amendments to the laws directly into the text of the Law "On State Budget", which was repeatedly the

10 Про внесення змін до Податкового кодексу України та деяких законодавчих актів України щодо податкової реформи. Закон України від 28 грудня 2014 року № 71-VIII. URL: https://zakon.rada.gov.ua/laws/show/71-19 (дата звернення: 02.09.2019).

${ }^{11}$ Гетманцев Д.О., Коваль Ю.А., Нечай М.В. Адміністрування податкових платежів: проблеми теорії та практики: наук.практ.посіб. - К., 2017. - С. 50.

${ }^{12}$ Бюджетний кодекс України від 21 червня 2001 p. URL: https://zakon.rada.gov.ua/ laws/show/2542-14 (дата звернення: 02.09.2019).

${ }^{13}$ Там само. 
subject of review by the Constitutional Court of Ukraine. When deciding on the subject matter and content of the Law "On State Budget of Ukraine", the Constitutional Court referred to the decision in the case of social guarantees of citizens, according to paragraph 5 of the reasoning of which the Parliament of Ukraine, when adopting the Law "On State Budget of Ukraine", shall not be empowered to include therein provisions on amendments to the current laws of Ukraine, suspend certain laws of Ukraine and/or in any way change the legal regulation of social relations defined by other laws of Ukraine ${ }^{14}$.

In recent years, the legislator has not practiced incorporation of amendments to the laws into the text of the Law "On State Budget", but often these changes are adopted on the same day with the adoption of the State Budget, that is, in essence, a package of bills. Existence of a "budget package" for 2019 with the law envisaging amendments to the Tax Code of Ukraine was reported in the press ${ }^{15}$.

Similar information with regard to availability of the budget package appeared in the press when the State Budgets for $2016^{16}$ and for $2017^{17}$ were adopted.

Adoption of amendments to the tax legislation for changing the budget indicators of a particular tax year, in our opinion, does not take into account the stimulating and regulating functions of taxation, points out to the fact that the tax policy only adheres to current goals and objectives, without taking into account strategic and long-term goals. It is worth mentioning that in some cases, the relevant objectives even are implied by the legislative instrument. Such is the Law "On Amendments to Tax Code of Ukraine and Certain Legislative Instruments of Ukraine on Balancing Budget Revenues in 2017” No. 1791-VIII as of December 20,

${ }^{14}$ Рішення Конституційного Суду України від 22 травня 2008 року № 10-рп/2008 у справі щодо предмета та змісту закону про Державний бюджет України. URL: https://zakon.rada.gov.ua/laws/show/v010p710-08 (дата звернення: 02.09.2019); Рішення Конституційного Суду України від 9 липня 2007 року № 6-рп/2007 у справі про соціальні гарантії громадян. URL: https://zakon.rada.gov.ua/laws/show/v0a6p710-07 (дата звернення: 02.09.2019).

${ }_{15}$ Рада прийняла перший законопроект із «бюджетного пакету». Економічна правда. URL: https://www.epravda.com.ua/news/2018/11/22/642920/ (дата звернення: 02.09.2019).

16 Бюджетний пакет Мінфіну: стабілізація недорозвиненості. URL: https://dt.ua/ macrolevel/byudzhetniy-paket-minfinu-stabilizaciya-nedorozvinenosti-_.html (дата звернення: 02.09.2019).

${ }^{17}$ Бюджетний «пакет» в аграрному розрізі: головні новели. URL: https://agropolit.com/blog/184-byudjetniy-paket-v-agrarnomu-rozrizi-golovni-noveli (дата звернення: 03.09.2019). 
2016. It entered into force on January $01,2017^{18}$. As its name implies, this law amends the Tax Code in order to ensure balancing budget revenues in 2017. It is interesting that the amendments made by this law did not cease to be valid at the end of the year, but continue to operate as regulations of permanent nature.

On November 23, 2018, the Parliament adopted Law No. 2628-VIII "On Amendments to Tax Code of Ukraine and Some Other Legislative Instruments of Ukraine on Improving Administration and Revision of Rates of Certain Taxes and Fees"19. This Law came into force on January 01, 2019, pointing out to the fact that breach of the taxation stability principle is ongoing and systematic.

No transition period with regard to penalties. When the Tax Code was adopted, the legislator imposed a moratorium on penalties, envisaging the rule in paragraph 7 subsection 10 section XX "Transitional Provisions" of the Code, according to which penalties for violation of the tax legislation for the period from January 01 to June 30, 2011 shall apply in the amount of not more than 1 UAH for each violation ${ }^{20}$.

Subsequently, this approach was supported, and having incorporated in 2012 the regulations on the simplified system of taxation of small business entities in the text of the Code, the Parliament by its Law No. 4834-VI as of May 24, 2012 envisaged that penalties against single tax payers for violations in 2012 of the procedure for calculation, accuracy of filling tax returns of single tax payer and completeness of payment of single tax amounts by the payers shall not be applied ${ }^{21}$. However, then the approaches changed. Even radically changing the taxation system without a proper transition period, the legislator now rarely imposes moratoriums on penalties. It is necessary to cite as an example, however, the provision of the aforementioned Law No. 71- VIII,

18 Про внесення змін до Податкового кодексу України та деяких законодавчих актів України щодо забезпечення збалансованості бюджетних надходжень у 2017 році. Закон України від 20 грудня 2016 p. URL: № 1791-VIII. https://zakon.rada.gov.ua/ laws/show/1791-19 (дата звернення: 03.09.2019).

19 Про внесення змін до Податкового кодексу України та деяких інших законодавчих актів України щодо покращення адміністрування та перегляду ставок окремих податків і зборів. Закон України від 23 листопада 2018 р. № 2628-VIII. URL: https://zakon.rada.gov.ua/laws/show/2628-viii (дата звернення: 03.09.2019).

${ }^{20}$ Податковий кодекс України від 2 грудня 2010 p. URL: https://zakon.rada.gov.ua/ laws/show/2755-17/ed20190101 (дата звернення: 03.09.2019).

21 Про внесення змін до Податкового кодексу України щодо удосконалення деяких податкових норм. Закон України від 24 травня 2012 р. № 4834-VI. URL: https://zakon.rada.gov.ua/laws/show/4834-17\#n516 (дата звернення: 03.09.2019). 
under which, according to the results of activity in 2015, penalties (financial sanctions) against payers of corporate income tax for violation of the procedure for calculation, accuracy of filling tax returns of single taxpayer and completeness of payment thereof shall not be applied. At the same time, this law introduced systematic changes not only to the procedure for payment of income tax, but also to almost every tax for which there was no moratorium on penalties.

Introduction and abolition of retail taxes "today starting from today". Sometimes, without any transition period, the legislator essentially establishes or abolishes taxes that apply to an extremely wide range of taxpayers and require substantial preparatory work, since their collection requires the use of certain organizational and technical mechanisms. To do this, we would like to cite two important examples with regard to introduction and abolition of retail excise tax.

The first example. The mentioned Law No. 71-VIII introduced a retail excise tax - excise tax on retail trade in excisable goods (fuel, alcohol, tobacco). This tax had to deal with the maximum retail price for tobacco products and was added to the retail price for alcohol and tobacco by retailers. Thus, the law, which was adopted on December 28, 2014 and entered into force on January 01, 2015, applied to every retailer of excisable goods. Accordingly, each of them had to re-equip (reconfigure) the cash registers in the short term so as to be able to pay this tax, keep its accounting and provide reporting. It is clear that it is impossible to do this in 1-2 days all over Ukraine, so for a certain period in January-February 2015, entrepreneurs and legal entities had to pay this tax from at their own expense (during the period when retail sales of excisable goods were made, however, these entities have not yet managed to reconfigure the cash registers). This example shows that entrepreneurs have incurred real losses as a result of non-compliance by the legislator with the taxation stability principle.

The first example also confirms that adherence to the stability principle is objectively necessary, since the mechanism of taxation with certain taxes requires the use of technical means, and objectively requires some time. In addition, despite the fact that ignorance of the laws does not exempt from liability, it is objectively necessary to provide taxpayers with the opportunity to read the texts of the laws. The laws on amendments to the Tax Code of Ukraine set forth in several dozen pages cannot always be read in one day. Of course, one should not assume that most taxpayers will do it. And it follows that the taxpayers will 
unconsciously violate the law in the initial stages, and for elimination of such violations they will have to resort to falsification (drafting accurate documents retroactively) or will be held liable for the offenses, committed, essentially not due to their fault.

Almost as interesting is the second example. Law No. 1791-VIII "On Amendments to Tax Code of Ukraine and Some Legislative Instruments of Ukraine on Balancing Budget Revenues in 2017” was adopted on December 20, 2016 and enacted on January 01, 2017. This Law abolished the excise tax on retail trade in fuel ${ }^{22}$. It can be assumed that, for a few days or weeks, all retail fuel business entities that had cash registers and were ready to pay excise tax, prior to reverse cash registers adjustment, collected this tax from customers and eventually left it to themselves, and did not pay it to the budget, and if they did, they did it without a tax obligation to pay it.

\section{Legal technique peculiarities}

Laws publication with delay. We also consider it necessary to raise the issue of timely publication of the tax laws adopted in the last days of the year. For example, the aforementioned Law No. 71-VIII was published in the special issue of the "Holos Ukrainy" (Voice of Ukraine) newspaper (official newspaper of Ukrainian parliament) on December 31, 2014. Official information on the website of the Parliament states that Bill No. 1578 which later became Law No. 71-VIII was signed by the Chairman of the Verkhovna Rada of Ukraine on December 31, submitted for signing to the President on December 31 and returned by the President on the same day, on December 31, 2014. Of course, the law could have not been physically promulgated on December 31, 2014. And if the special issue of the "Holos Ukrainy" newspaper was published or even printed on December 31, 2014 (after the Law was signed by the President), it is unlikely that one of the readers could have read the text of the Law on December 31, $2014^{23}$.

22 Про внесення змін до Податкового кодексу України та деяких законодавчих актів України щодо забезпечення збалансованості бюджетних надходжень у 2017 році. Закон України від 20 грудня 2016 р. № 1791-VIII. URL: https://zakon.rada.gov.ua/laws/ show/1791-19 (дата звернення: 03.09.2019).

23 Про внесення змін до Податкового кодексу України та деяких законодавчих актів України щодо податкової реформи. Закон України від 28 грудня 2014 року № 71-VIII. URL: https://zakon.rada.gov.ua/laws/show/71-19 (дата звернення: 03.09.2019). 
According to the author's own mentions, which unfortunately cannot be verified with credible scientific evidence, this special issue appeared on the website of the "Holos Ukrainy" newspaper on January 02, 2014, when it went on sale in newsstands - it is quite difficult to say (considering the fact that on the $1^{\text {st }}$ of January - New Year's Day is an official holiday in Ukraine, not a business day).

Therefore, urgent adoption and enforcement of the tax laws leads to possible delays in their publication, which in its turn means that for some time legal relations are governed by the unpublished law. At the same time, since business operates on public holidays, this may be relevant for taxation of business transactions taking place on such public holidays, and further emphasizes the necessity for publication of laws in advance (with a proper transition period).

Technical errors in the texts of laws. Adoption of amendments to the tax laws in packages, non-compliance with established parliamentary procedures and the 6-month transition period under consideration lead to far more technical errors in the texts of the tax laws than may be acceptable. Sometimes such errors remain uncorrected for several years in a row, resulting in legal uncertainty or creating an area of poor legal regulation. Perhaps, the most well-known of these regulations-errors is the technical regulation on enactment of the regulation on abolition of the tax militia (police organisation for tax criminal investigation), contained in Law No. 1797-VIII "On Amendments to Tax Code of Ukraine on Improving Investment Climate in Ukraine” as of December 21, 2016. The whole section was excluded from the Tax Code only due to inaccurate reference to the item number in the text of the amendment.

Paragraph 134 of Section I of this Law envisaged exclusion of Section XVIII-2 “Tax Miliia” from the text of the Criminal Procedure Code. On the whole, the Law entered into force on January 01, 2017. However, the procedure under which it entered into force contained the regulation with the exception as regards entry into force of "paragraph 133, Section I (with regard to exclusion of Section XVIII-2) upon the date of entry into force of the law defining the legal grounds for arrangement and activity of a central executive body charged with the duty to ensure prevention, detection, termination, investigation and disclosure of criminal offenses the subject of which is the financial interests of the State and/or local authorities, falling within its jurisdiction under the Criminal Procedure Code of Ukraine and other persons with whom such body interacts.” Inherently, in preparation and 
editing of the text of amendment, the numbering of items was moved up and paragraph 133 became paragraph 134. However, as a result, the Section of the Tax Code of Ukraine on tax militia was deleted on January 01, $2017^{24}$.

In his interview in 2018, the Finance Minister of Ukraine acknowledged that the tax militia existed outside the law but the budget funds were still allocated for its needs ${ }^{25}$. Undoubtedly, given that the tax militia is the pre-trial investigation body, this situation in law is absolutely unacceptable.

The second known serious technical error is Article 78 of the Tax Code of Ukraine envisaging the grounds for unscheduled on-site inspections of taxpayers, in particular, as a result of their failure to respond to a mandatory written request from the supervisory authority. Thus, paragraph 78.1.1 of the Tax Code of Ukraine as amended by Law No. 909-VIII "On Amendments to Tax Code of Ukraine and Certain Legislative Instruments of Ukraine on Balancing Budget Revenues in 2016” as of December 24, 2015, which entered into force on January 01, 2016, provides for the possibility of an unscheduled audit in case of "receipt of tax information pointing out to violation by the taxpayer of currency and other legislation laws that have not been regulated by this Code, the control of which is vested upon the regulatory bodies". The possibility to carry out an unscheduled audit in case of detection of any breach of the tax legislation disappeared in a strange way from the text of the regulation (which is quite logical, since it is a matter of the Tax Code and regulatory bodies are tax inspections) ${ }^{26}$. This technical error was corrected only by Law No. 1797-VIII as of December 21, $2016^{27}$.

From the point of view of legal technique, it is quite interesting that the amendments have been introduced twice to paragraph 78.1.2 of the

${ }^{24}$ Про внесення змін до Податкового кодексу України щодо покращення інвестиційного клімату в Україні. Закон України від 21 грудня 2016 року № 1797-VIII. URL: https://zakon.rada.gov.ua/laws/show/1797-19 (дата звернення: 03.09.2019).

${ }^{25}$ Мінфін: податкова міліція вже більше року існує поза законом. URL: https://www.5.ua/polityka/minfin-podatkova-militsiia-vzhe-ponad-rik-isnuie-poza-zakonom165557.html (дата звернення: 03.09.2019).

${ }^{26}$ Про внесення змін до Податкового кодексу України та деяких законодавчих актів України щодо забезпечення збалансованості бюджетних надходжень у 2016 році. Закон України від 24 грудня 2015 р. № 909-VIII. URL: https://zakon.rada.gov.ua/laws/ show/909-19 (дата звернення: 03.09.2019).

${ }^{27}$ Про внесення змін до Податкового кодексу України щодо покращення інвестиційного клімату в Україні. Закон України від 21 грудня 2016 року № 1797-VIII. URL: https://zakon.rada.gov.ua/laws/show/1797-19 (дата звернення: 03.09.2019). 
Tax Code of Ukraine by two different laws, dated December 28, 2014. Law No. 71-VIII supplemented the provision of this paragraph by certain words, and Law No. 72-VIII outlined the provision of this paragraph in a new wording. Both laws entered into force on January 01, 2015. It is difficult to say which of the amended regulations prevails ${ }^{28}$.

We assume that when the Parliament has sufficient time to review, elaborate and edit the bill, its review in accordance with the regulation and without violating the regulations of other laws, then the possibility of technical errors is significantly reduced.

\section{Why does the stability principle not work?}

When a legislator enacts a law which, contrary to the provisions of the Tax Code of Ukraine (TCU) and the Budget Code, changes the taxation rules without establishing at least a 6-month transition period, the taxpayers and regulatory authorities receive two laws that contradict each other. One of the laws - the Tax Code of Ukraine, establishing the relevant principle, prohibits to amend the tax law under such procedure. The second law, violating this prohibition, makes such amendment and sets other taxation rules. In other words, the second law contradicts the first one. When settling a conflict of the legal rules with the same legal effect, we prefer a special regulation, that is the regulation making an amendment. Because the regulation-principle is always general in relation to a specific regulation that contains an indication of certain rights and obligations. However, there are no constitutional or organic laws in Ukraine, and therefore the regulations of all laws, except for the Constitution, have the same legal effect.

This problem may be solved by a specific taxpayer only if the regulatory authority charges the tax and/or holds the taxpayer liable for the tax offense under the amended regulation, and the taxpayer will prove in court that the tax was charged against the law and/or he was held liable for the offense committed not due to his fault, and it occurred solely as a result of violations committed by the legislator when adopting the amendments to the tax law and determining the procedure for its entry into force.

Such situations may be observed in the case law. The most wellknown are the dozens of litigations concerning implementation of a transport tax without observing the transition period.

${ }^{28}$ Про внесення змін до Податкового кодексу України щодо удосконалення податкового контролю за трансфертним ціноутворенням. Закон України від 28 грудня 2014 р. № 72-VIII. URL: https://zakon.rada.gov.ua/laws/show/72-19 (дата звернення: 03.09.2019). 
Tax imposition without observing transition period. Some of the said cases have already been submitted to the Supreme Court and have been mainly settled in favour of the taxpayer. Thus, the Supreme Court by its decision dated August 21, 2018 in case No. 820/6986/16 upheld the decisions of the administrative court of first instance and administrative appellate court, taken in favour of the taxpayer in the dispute, under which the authority charged the transport tax with a person for 2015, introduced on January 01, 2015 by Law No. 71-VIII dated 28.12.2014, based on the regulations of the Tax Code of Ukraine (taking into account the amendments made by the said Law) and the corresponding decision of the local council, since the transport tax is (in our opinion, technically) a local tax necessarily imposed by the local councils.

The position of the regulatory authority in this case is interesting, which is quite typical in such cases. Thus, in order to substantiate its requirements, the tax inspection noted that "the stability principle is applied in the case of amendments to the elements of taxes and duties, and not in the adoption of new taxes, whereas a new transport tax was introduced by Law of Ukraine No. 71-VIII "On Amendments to Tax Code of Ukraine and Some Laws of Ukraine on Tax Reform” as of December 28, $2014^{29}$.

Settling this dispute, the Supreme Court pointed out that "the decisions of local councils with regard to the transport tax, taken in 2015, could not be applied in the same year 2015. Such decisions could determine only 2016 as a planning year, and it the transport tax could be considered established by the local council only starting from this year”. Substantiating this decision, the Supreme Court refers to the stability principle (cl. 4.1 of the Tax Code), Article 58 of the Constitution of Ukraine (stating that the laws have no retroactive effect), Article 57 of the Constitution (according to which everyone is guaranteed the right to know his/her rights and obligations) ${ }^{30}$ and the ECHR decisions in the cases of Shchokin v. Ukraine and Sukhanov and Ilchenko v. Ukraine ${ }^{31}$.

We can draw an important conclusion from the above decision of the Supreme Court. The stability principle applies not only to amendments to

29 Постанова Верховного Суду від 21 серпня 2018 року у справі №820/6986/16. URL: http://www.reyestr.court.gov.ua/Review/76002788 (дата звернення: 03.09.2019).

${ }^{30}$ Конституція України від 28 червня 1996 p. URL: https://zakon.rada.gov.ua/ laws/show/254к/96-вр (дата звернення: 03.09.2019).

31 Case of Shchokin v. Ukraine (Applications nos. 23759/03 and 37943/06). URL: http://hudoc.echr.coe.int/eng?i=001-100944 (дата звернення: 03.09.2019) ; Case of Sukhanov and Ilchenko v. Ukraine (Applications nos. 68385/10 and 71378/10). URL: http://hudoc.echr. coe.int/eng?i=001-145014 (дата звернення: 03.09.2019). 
the elements of taxes and duties, but also to the introduction of new taxes. Besides, the mention in the decision of the Constitutional Court concerning any person's right to know his/her rights and obligations is extremely important. In the above situations, the publication of amendments to tax laws with delay, their late adoption undoubtedly infringes this constitutional right.

One of the problems related to tax policy in disputes with taxpayers is that the regulatory authorities implement the practice of appealing against court decisions taken not in their favour, even in cases where the law (and in some cases - the relevant case law) is clearly not on their side (as we can see in the above case). In our opinion, this is unreasonable. If a court decision is taken in favour of taxpayers, the regulatory authority should really assess its chance of "winning the case" in court on the basis of the results of appeal and cassation review. In such a case, where the case law is clearly not in favour of the regulatory authorities (which proves the illegality of their decisions, actions or omissions actually contested by the taxpayer), the appeal of the court decisions is a waste of the taxpayers' money and, in our opinion, does not contribute to the establishment of the rule of law (when the public authority insists on the accuracy of its manifestly unlawful position). Of course, the heads of regulatory authorities, when taking decisions upon the results of the audits, should also evaluate the case law and sufficiently examine the taxpayer's explanations and objections, so that the decisions of the regulatory authorities would be lawful and justified. In order to reduce the number of taxpayers' claims in court, K. Priamitsyn proposes to legislate personal responsibility of the officials of the regulatory authorities for making unreasonable decisions on imposing tax liabilities ${ }^{32}$. The above question is a problem that requires more detailed independent scientific research.

O. R. Zeldina, emphasizing that real, not declared tax stability should be one of the directions of reforming tax policy, therefore proposes to establish responsibility for law-makers who violate the stability principle $^{33}$.

32 Пряміцин К.Ю. Судовий збір у податкових спорах як фактор обмеження доступу до правосуддя. // Вісник Національного технічного університету України «Київський політехнічний інститут». Політологія. Соціологія. Право. - 2018. - № 3. C. 150 .

33 Зельдіна О. Напрями модернізації податкової політики України. // Юридична Україна. 2017. - № 1-2. - С. 103-110. 
In our opinion, given the high importance of the problem for tax regulation, it is necessary to provide for a rule of tax stability at the level of the Constitution. It is expected to lead to a more prudent tax and customs policy and make a positive impact on economic development, increase business confidence in the authorities and promote the rule of law.

\section{CONCLUSIONS}

1. Tax legislation of Ukraine is more dynamic than stable. The Tax Code of 2010 is one of the largest and most complicated and, at the same time, the most amended laws of Ukraine. Notwithstanding, the tax laws of Ukraine have restrictions, existing over 25 years, on amending the basic elements of tax laws after July 1 of the year preceding the tax year. The Government and Parliament traditionally violate this rule.

2. One of the main manifestations of modern tax policy should be the real observance of the stability principle, according to which amendments to the tax legislation and adoption of its new regulations should be made in compliance with the statutory requirements for a minimum 6-month transition period for their entry into force.

Observation of the principle of the stability in tax regulation and tax policies should be ensured in the light of the following:

- as a manifestation of observance of the principle of the rule of law by the legislative and executive bodies in the form of non-performance of actions prohibited by the law;

- due to physical inability of taxpayers to study amendments to the tax laws in due time, inasmuch as they have traditionally large volume, and, as result, it violates the constitutional right of a person to know his rights and obligations;

- in order to ensure the higher quality of the amendments to the tax laws, it is advisable to adopt them without any deviation from the standard procedure, without recognizing them as urgent and without including in various kinds of "packages", when the members of Parliament are not able to read in detail and propose and consider amendments to the bill;

- due to the need for applying organizational and technical measures and means in taxation with some taxes (for example, setting up and reconfiguring registrars of accounting transactions, computer programs for accounting and reporting automation, updating forms, etc.), which need some time for setting in the event of significant changes in the tax mechanism. 
3. In order to comply with the stability principle, tax policy should be based on the following approaches:

- the subjects of legislative initiative have no right to draft and submit to the Parliament bills that envisage amendments to the Tax Code with their entry into force contrary to the stability principle established by the Tax Code (without observing the minimum 6-month transition period);

- the Parliament should not adopt such bills if they are received; and if such a bill is to be adopted, it will have to be amended in order to take effect from the next fiscal year following the planning year;

- in the event of such amendments being adopted by the Parliament, the regulatory authorities have to consider the relevant amendments to be effective only from the next fiscal year;

- in the event of a dispute over the entry into force of the tax rule (both when declaring taxes by the taxpayer, and when levying by the regulatory authority, upon the results of the audit or in the course of court proceedings), it must be resolved in favour of the taxpayer, to the extent of tax regime maximum favourable to the taxpayer.

4. In order to ensure the effective functioning of the stability principle in tax policy, it is reasonable to provide for a regulation of tax stability at the level of the Constitution. For this purpose, the author proposes to supplement Article 67 of the Constitution of Ukraine with the sentence (new part) with the following content:

"The new taxes and duties cannot be introduced, and the laws on introducing the new taxes and duties and amendments to tax and duties rules cannot be adopted and published later than six months before the start of the new fiscal year, in which the new taxes, rules and rates will be applicable" ${ }^{34}$.

5. Within the framework of the current legislation, in the event of any disputes between a taxpayer and a regulatory authority, the courts should take a decision in favour of the taxpayer in the cases when amendments to the tax laws introduced without compliance with the stability principle have led to imposition of taxes, recovery of duties and/or application of sanctions).

${ }^{34}$ Кравчук О. О. Стабільність оподаткування має стати ключовим принципом податкової політики. // Вісник Національного технічного університету України «Київський політехнічний інститут». Політологія. Соціологія. Право. - 2018. - № 4. C. 127-135. URL: http://nbuv.gov.ua/UJRN/ (дата звернення: 03.09.2019). 
6. Under the current Tax Code, taking into account the case law of the Supreme Court, the stability principle in taxation applies not only to amendments to the elements of taxation, but also to introduction of new taxes.

Development of an attractive investment economy in Ukraine requires the stability and clarity of tax legislation. Therefore, the Government and Parliament should take this into consideration in the course of drafting amendments to tax policy, tax laws and implementing thereof.

\section{SUMMARY}

System disadvantages hindering compliance with the taxation stability principle are considered. The stability principle in the tax law of Ukraine appeared in the Law of Ukraine “On Taxation System” in 1994 and it is provided by tax legislation all 25 years from 1994 till 2019. Due to stability principle amendments to the tax laws should be available at least 6 months prior to the beginning of the fiscal year. However, the Parliament was not concerned about stability principle and, if necessary, they amended the tax laws and brought them into force immediately or with a much shorter transition period than 6 months.

Under the current Tax Code, taking into account the case law of the Supreme Court, the stability principle in taxation applies not only to amendments to the elements of taxation, but also to introduction of new taxes.

Approaches in tax and legal regulation, which should ensure prevention from violation of stability principle are proposed. In order to comply with the stability principle, tax policy should be based on the following approaches. The subjects of legislative initiative have no right to draft and submit to the Parliament bills that envisage amendments to the Tax Code with their entry into force contrary to the stability principle established by the Tax Code (without observing the minimum 6-month transition period). The Parliament should not adopt such bills if they are received; and if such a bill is to be adopted, it will have to be amended in order to take effect from the next fiscal year following the planning year. In the event of such amendments being adopted by the Parliament, the regulatory authorities have to consider the relevant amendments to be effective only from the next fiscal year.

In the event of a dispute over the entry into force of the tax rule (both when declaring taxes by the taxpayer, and when levying by the regulatory authority, upon the results of the audit or in the course of court 
proceedings), it must be resolved in favour of the taxpayer, to the extent of tax regime maximum favourable to the taxpayer.

In order to ensure the effective functioning of the stability principle in tax policy, it is reasonable to provide for a regulation of tax stability at the level of the Constitution.

\section{REFERENCES}

1. Про Міністерство доходів і зборів України. Указ Президента України від 18 березня 2013 р. № 141/2013. URL: https://zakon.rada.gov.ua/laws/show/141/2013 (дата звернення: 02.09.2019).

2. Про утворення Державної фіскальної служби. Постанова Кабінету Міністрів України від 21 травня 2014 p. № 160. URL: https://zakon.rada.gov.ua/laws/show/160-2014-п (дата звернення: 02.09.2019).

3. Гетманцев Д.О., Коваль Ю.А., Нечай М.В. Адміністрування податкових платежів: проблеми теорії та практики: наук.-практ. посіб. - К., 2017. - С. 50.

4. Про систему оподаткування. Закон України. В редакції Закону України «Про внесення змін і доповнень» до Закону Української РСР «Про систему оподаткування» від 2 лютого 1994 року № 3904-XII. URL: https://zakon.rada.gov.ua/laws/show/3904-12/ ed19940401 (дата звернення: 02.09.2019).

5. Про внесення змін до Закону України «Про систему оподаткування. Закон України від 18 лютого 1997 року № 77/97-ВР.» URL: https://zakon.rada.gov.ua/laws/show/77/97-вp/ed20000331 (дата звернення: 02.09.2019).

6. Про внесення змін до деяких законодавчих актів України 3 питань оподаткування. Закон України від 2 березня 2000 p. № 1523-III. URL: https://zakon.rada.gov.ua/laws/show/1523-14/ ed20040101 (дата звернення: 02.09.2019).

7. Уряд схвалив законопроект щодо запровадження податку на виведений капітал. URL: https://www.kmu.gov.ua/ua/news/250326805 (дата звернення: 02.09.2019).

8. Картка законопроекту. Проект Закону про внесення змін до Податкового кодексу України щодо податку на виведений капітал. Реєстр. №8557 від 05.07.2018. URL: http://w1.c1.rada.gov.ua/pls/ zweb2/webproc4_1?pf3511=64356 (дата звернення: 02.09.2019). 
9. Економічні законопроекти від нових депутатів, зареєстровані в ВРУ. Дебет-Кредит. URL: https://news.dtkt.ua/state/laws-andregulations/57423 (дата звернення: 02.09.2019).

10. Податковий кодекс України від 2 грудня 2010 p. URL: https://zakon.rada.gov.ua/laws/show/2755-17/ed20190101 (дата звернення: 02.09.2019).

11. Про внесення змін до Податкового кодексу України та деяких законодавчих актів України щодо податкової реформи. Закон України від 28 грудня 2014 року № 71-VIII. URL: https://zakon.rada.gov.ua/laws/show/71-19 (дата звернення: 02.09.2019).

12. Бюджетний кодекс України від 21 червня 2001 p. URL: https://zakon.rada.gov.ua/laws/show/2542-14 (дата звернення: 02.09.2019).

13. Бюджетний кодекс України від 8 липня 2010 p. URL: https://zakon.rada.gov.ua/laws/show/2456-17 (дата звернення: 02.09.2019).

14. Рішення Конституційного Суду України від 22 травня 2008 року № 10-рп/2008 у справі щодо предмета та змісту закону про Державний бюджет України. URL: https://zakon.rada.gov.ua/laws/ show/v010p710-08 (дата звернення: 02.09.2019).

15. Рішення Конституційного Суду України від 9 липня 2007 року № 6-рп/2007 у справі про соціальні гарантії громадян. URL: https://zakon.rada.gov.ua/laws/show/v0a6p710-07 (дата звернення: 02.09.2019).

16. Рада прийняла перший законопроект із «бюджетного пакету». Економічна правда. URL: https:/www.epravda.com.ua/news/ 2018/11/22/642920/ (дата звернення: 02.09.2019).

17. Бюджетний пакет Мінфіну: стабілізація недорозвиненості. URL: https://dt.ua/macrolevel/byudzhetniy-paket-minfinu-stabilizaciyanedorozvinenosti-_.html (дата звернення: 02.09.2019).

18. Бюджетний «пакет» в аграрному розрізі: головні новели. URL: https://agropolit.com/blog/184-byudjetniy-paket-v-agrarnomurozrizi-golovni-noveli (дата звернення: 03.09.2019).

19. Про внесення змін до Податкового кодексу України та деяких законодавчих актів України щодо забезпечення збалансованості бюджетних надходжень у 2017 році. Закон України від 20 грудня 2016 р. № 1791-VIII. URL: https://zakon.rada.gov.ua/laws/ show/1791-19 (дата звернення: 03.09.2019). 
20. Про внесення змін до Податкового кодексу України та деяких інших законодавчих актів України щодо покращення адміністрування та перегляду ставок окремих податків і зборів. Закон України від 23 листопада 2018 р. № 2628-VIII. URL: https://zakon.rada.gov.ua/laws/show/2628-viii (дата звернення: 03.09.2019).

21. Податковий кодекс України від 2 грудня 2010 p. URL: https://zakon.rada.gov.ua/laws/show/2755-17/ed20190101 (дата звернення: 03.09.2019).

22. Про внесення змін до Податкового кодексу України щодо удосконалення деяких податкових норм. Закон України від 24 травня 2012 p. № 4834-VI. URL: https://zakon.rada.gov.ua/laws/show/ 4834-17\#n516 (дата звернення: 03.09.2019).

23. Про внесення змін до Податкового кодексу України щодо покращення інвестиційного клімату в Україні. Закон України від 21 грудня 2016 року № 1797-VIII. URL: https://zakon.rada.gov.ua/ laws/show/1797-19 (дата звернення: 03.09.2019).

24. Мінфін: податкова міліція вже більше року існує поза законом. URL: https://www.5.ua/polityka/minfin-podatkova-militsiiavzhe-ponad-rik-isnuie-poza-zakonom-165557.html (дата звернення: 03.09.2019).

25. Про внесення змін до Податкового кодексу України та деяких законодавчих актів України щодо забезпечення збалансованості бюджетних надходжень у 2016 році. Закон України від 24 грудня 2015 р. № 909-VIII. URL: https://zakon.rada.gov.ua/laws/ show/909-19 (дата звернення: 03.09.2019).

26. Про внесення змін до Податкового кодексу України щодо удосконалення податкового контролю за трансфертним ціноутворенням. Закон України від 28 грудня 2014 р. № 72-VIII. URL: https://zakon.rada.gov.ua/laws/show/72-19 (дата звернення: 03.09.2019).

27. Постанова Верховного Суду від 21 серпня 2018 року у справі № 820/6986/16. URL: http://www.reyestr.court.gov.ua/Review/76002788 (дата звернення: 03.09.2019).

28. Конституція України від 28 червня 1996 p. URL: https://zakon.rada.gov.ua/laws/show/254к/96-вр (дата звернення: 03.09.2019).

29. Case of Shchokin v. Ukraine (Applications nos. 23759/03 and 37943/06). URL: http://hudoc.echr.coe.int/eng?i=001-100944 (дата звернення: 03.09.2019). 
30. Case of Sukhanov and Ilchenko v. Ukraine (Applications nos. 68385/10 and 71378/10). URL: http://hudoc.echr.coe.int/eng?i= 001-145014 (дата звернення: 03.09.2019).

31. Пряміцин К.Ю. Судовий збір у податкових спорах як фактор обмеження доступу до правосуддя. // Вісник Національного технічного університету Украӥни «Київський політехнічний інститут». Політологія. Сочіологія. Право. - 2018. - № 3. - С. 150.

32. Зельдіна О. Напрями модернізації податкової політики України. // Юридична Україна. 2017. - №1-2. - С. 103-110.

33. Кравчук О. О. Стабільність оподаткування має стати ключовим принципом податкової політики. // Вісник Національного технічного університету Украӥни «Київський політехнічний інститут». Політологія. Соціологія. Право. - 2018. - № 4. - С. 127-135. URL: http://nbuv.gov.ua/UJRN/ (дата звернення: 03.09.2019).

Information about the author: Kravchuk O. O. Doctor of Law (Dr.Hab.), Professor at the Department of Businness Law and Administrative Law, Igor Sikorsky Kyiv Polytechnic Institute 37, Peremohy Ave., Kyiv, 03056, Ukraine 